\title{
Liturgical renovation of modern churches in Rome (Italy)
}

\author{
Daniela Concas ${ }^{1}$ \\ I'Sapienza', University of Rome, Faculty of Architecture - UNIROMA1 - Rome, Italy \\ Email:daniela.concas@uniroma1.it
}

\begin{abstract}
At the beginning of the first half of the twentieth century the bond between ars-venustas and cultus-pietas has produced many churches of Roman Catholic cult.

It's between the 20s and 60s of the twentieth century that the experiments of the Liturgical Movement in Germany lead to the evolution of the liturgical space, which, even today, we see engraving in modern churches in Rome (Italy).

The Council of Trent (1545-1563) constitutes the precedent historical moment, in which the Church recognised the need for major liturgical renovation of its churches. In comparison with this, the Second Vatican Council (1959-65) introduced some radical changes within the church architectural spaces.

The observations come from the direct reading of the present architectural space and the interventions already realised in modern churches in Rome. The most significant churches from an historical-artistic point of view were selected (1924-1965). Significantly, although every single architecture is unique for dimensions, architectural language and used materials, a comparison, in order to gather the discovered characteristics and to compare the restrictions regarding the different operations, would extremely effective, as demonstrated below.

Since the matter is considerably vast, in this work, only some brief notes regarding the liturgical renovation of the Presbytery area will be outlined.
\end{abstract}

(C) 2019 The Authors. Published by IEREK press. This is an open access article under the CC BY license (https://creativecommons.org/licenses/by/4.0/).

\section{Keywords}

Churches; Liturgical renovation; Second Vatican Council; Conservation; Rome.

\section{Introduction}

Since 1920 it has been already spoken about conceiving a new urban plan for Rome (Italy), to face the 'housing crisis', that would have replaced the current General Urban Development Plan - GUDP dating back to 1909. After a General Variation between the years 1925 and 1926, the GUDP is approved in 1931 and it calculates a population doubling of 2 milion of people by its expiry date (25 years). In order to meet such an increasement, the GUDP determines an urban extension limit and includes intensive structures that are located everywhere in the city and characterized by residential buildings expressing a specific social class, but that are all bond to the road system. Churches are well arranged by the GUDP because they are considered qualifying aesthetic-moral representations in the urban arrangement, joining the public buildings, the city services, the houses, the road network, and because, as monuments, they are efficient means to break the monotony of modern districts (Concas, 2018a, p. 55-56).

From the religious point of view, these new districts raise new necessities. Now is all about bringing back to life an almost dead religiousness and giving new religious and worship reference points that are undermined by fast social changes. Starting from the Thirties, the pastoral activities begin to involve various religious orders, male and female 
ones, coming from the whole Italy to Rome. They had the task of taking care of people souls with religious help, evangelism, catechism teaching, home-based support for older and diseased people, etc. During these years, people find support in parish centres that acquire a deeper role for their social life and even more for their daily life because everything meets there: all the religious, associative, didactic, leisure, helpful and charity moments (Concas, 2018a, p. 57).

\section{The relationship between ars-venustas and cultus-pietas}

Over the centuries the relationship between ars-venustas and cultus-pietas led to an immeasurable and amazing heritage of churches under the liturgical purpose of Roman Catholic religion. The subdivision in functional spaces destined to the different rituals with their own specific movements and gestures has defined, then, the plan, the volumes and the structure of the architectural organism. The different kind of planimetry (to nave and aisles, to unique nave, central, to greek cross and intermediary) depends on the historic period, the customs and traditions, and the style of that period. From the second half of the 19th century, it is impossible to define a preferred type of architectural plan due to a wide composition freedom that denies any compromise with the modern side, having, then, a historicismoriented and eclectic attitude, but that takes advantage of the various technical uses of modern materials. However, the renovation works on the cultural space arrangement in Europe have been already in progress at the beginning of the 20th century and they can be seen in the churches of St. Coloma, inside Parc Güell in Barcelona (Arch. Antoni Gaudí 1908-15) and of St. Leopold (Arch. Otto Wagner 1904-07) and of Holy Spirit (Arch. Jože Plecnik 1910-13) in Vienna (Debuyst, 2003, p. 32). For all these three churches and thanks to the structural skills of reinforced concrete, it is wanted a type of architectural plan that allows the believer approach to the rite, following the style guidelines of the organic architecture for the first mentioned church and of Art Nouveau for the second ones.

From the 1st September 1924 the Pontifical Central Commission for Sacred Art in Italy must also examine the drawings of new religious buildings and give quality-oriented advices to designers and artists (it operates from 1924 to 1988 and is called Pontifical Commission for the Cultural Heritage of the Church). But, in order to fix promptly the expansion of Rome and the resulting spiritual necessities of clerical community, Pius XI establishes on the 5th August 1930 the Pontifical Society for the Propagation of the Faith and the Supply of New Churches in Rome (it operates from 1933 to 1956 and is called by John Paul II Roman Society for the Propagation of the Faith and the Supply of New Churches in Rome) (Concas, 2018a, p. 58-59). It is divided in two parts: the faith preservation, in order to face the protestant spread, and the building of new churches in Rome that have to take care of the parish churches foundation, even dismembering the old ones, the buying of new areas, the public authorities' procedures and the creation of parish centres. The Pontifical Society guidelines suggest to build a parish centre close to the church that needs an altar, a baptismal font, a confessional and a pulpit and must be spacious, solid, well illuminated, respectable and simple according to small economic resources and the few materials used (Concas, 2018a, p. 59-60).

It is interesting to highlight the consolidation, in just three years, of the relationship between State and Church through the signing of the Lateran Treaty in 1929, the establishment of the Pontifical Society in 1930 and the PRGC approval in 1931. It is also important that the Holy See commissions the building of new churches, in response to the growing urban expansion that will lead to an increase of parishes in the Diocese of Rome, going from 58 in 1900 up to 136 in 1950 (Santi, 2011, p. 51).

Between the two World Wars, the requests of a fast building and the economic limit of the Pontifical Society are accepted, but without sacrificing the clear recognisability of churches as worship places, by keeping the Christian tradition, especially the medieval one: it is preferred a longitudinal plan, mainly without transept and with an extrados semi-circular or quadrangular apse, that is modernized according to personal parameters (Concas, 2018a, p. 64). It is generally chosen an immediately recognizable and simple liturgical structure following what happened with Berlage in the Netherlands some decades before (Benedetti, 2003, p. 184), having simpler lines, pure shapes, severe cuts, volumes for blocks, an architecture 'bareness' without any unnecessary decorative objects, with a very well illuminated hall, a strict construction manner and, mainly, structures made of reinforced concrete instead of stones. 
In the second post-war, instead, a new period for the liturgical architecture begins because it is wanted to adopt the experimentations of the Liturgical Movement in Germany, due to the post-war rebuilding and the cities expansion with a growth of suburbs, and the ones of the encyclical Mediator Dei on the sacred liturgy issued by Pius XII (Concas, 2015, p. 71-72) (Carbonara \& Concas, 2016, p. 164-166). The building now is transformed from a cultural condition as traditional temple into a domestic condition as home, aiming at an aesthetic purification and architectural rationalization, thanks to the skills of the materials used and the modern techniques. All that pre-empts the precepts of the Second Ecumenical Council of the Vatican (1959-65). It is important to notice that the Liturgical Commission of German Episcopal Conference presented in Germany, in 1947 already, The guidelines for church building according to the roman liturgy spirit, meanwhile the Italian Episcopal Conference will publish in 1993 the pastoral Note called The planning of new churches that mentions some method choices and general reference points.

In the three naves planimetry, reference of tradition, the width of the main nave, and in some examples its height too, is often accentuated in relation to the aisles: in the first case, the width is doubled in S. Leone Magno in Prenestino district (Arch. Giuseppe Zander 1951-1952) and multiplied by six in S. Pio X in Balduina district (Arch. Alberto Ressa 1956-61); in the second case, there is an additional vertical rise thanks to the pillars on which the trusses of Natività di Nostro Signore in Via Gallia (Arch. Tullio Rossi 1937) are set upon. In S. Benedetto da Norcia in Ostiense district (Eng. Arch. Clemente Busiri Vici 1948), instead, the unique nave is asymmetrical due to the side chapels: on the right they are small and with constant depth, on the left they are tapered towards the presbytery area where the last chapel is symmetrical to the last one on the opposite side. Lastly, the wide nave with small chapels in S. Roberto Bellarmino in Parioli district (Eng. Arch. Clemente Busiri Vici and the brothers Arch. Michele and Andrea Busiri Vici 1931) opens up in a wide transept composed of two side pentagonal extrados chapels and ends in an apse of seven sides; in the middle of the transept there is a low drum with four pendentives upon which is set the cloister vault on octagonal base and with eight cylindrical patches; both the three polygonal apses and the octagonal vault recall the Cathedral S. Maria del Fiore in Florence.

Two churches, in particular, are considered the buildings in which the modern rules of 'Roman monumentality' have been applied first: the Sacro Cuore di Cristo Re in Delle Vittorie district (Arch. Marcello Piacentini 1924-38) and the church of SS. Pietro e Paolo in Eur district (Arch. Nello Ena, Alfredo Energici, Arnaldo Foschini, Vittorio Grassi, Tullio Rossi, Costantino Vetriani 1939-55), but they both recall traditional planimetries: the first one has a plan that mixes a greek cross shape and a latin cross shape, the second one, instead, has a greek cross plan. In the same way, the church of S. Giovanni Bosco in Tuscolano district (Arch. Gaetano Rapisardi 1953-58), born from this 'Roman monumentality', has a traditional planimetry with a latin cross shape.

Moreover, there are also liturgical structures in which it is noticed the influence of the Alemannia Liturgical Movement and, for the first time, the presence of a bigger hall where believers are allowed to attend the religious rituals having a total view of the place without obstacles. In the church of SS. Fabiano e Venanzio in Villa Fiorelli (Eng. Arch. Clemente Busiri Vici 1936), its three naves plan is seen as a unique space thanks to the enlargement done by high columns and their wide bays and to the homogeneity highlighted by the three naves with an almost similar height: this is the foretaste in Rome of the church of St Elisabeth Krankenhaus in Cologne (Arch. Dominikus Böhm 1928-32), just to mention a German example. Moreover, the parabolic arches of the nave in the churches of Sacro Cuore di Gesù Agonizzante in Vitinia (Arch. Ildo Avetta and Bruno Maria Apolloni Ghetti 1955) and Nostra Signora del Ss. Sacramento e dei SS. Martiri Canadesi in Villa Massimo (Arch. Bruno Maria Apollonj Ghetti 1950-55) represent a literal recall to the churches of St Apollinaris in Lindlar- Frielingsdorf (Arch. Dominikus Böhm 1926-28) and St. Bonifatius in Frankfurt-Sachsenhausen (Arch. Martin Weber 1931) and St. Marien in Limburg an der Lahn (Arch. Jan Hubert Pinand 1924-27).

\section{The liturgical renewal}

The Council of Trent (1545-1563) constitutes the previous historical moment in which the Church has felt the need of important interventions for a liturgical 'improvement' of its churches and the Instructiones Fabricae Ecclesiae et suppellectilis ecclesiasticaes for the Diocese of Milan issued by the cardinal Carlo Borromeo represent a sort of guidelines for the correct architectural and artistic creation. Up to the Second Vatican Council (1959 -65) the 
preaching and the spirit of devotion prevail. The ceremonial in particular, that happens inside a scenographic architecture, is drenched with solemn rituals, a grandeur in the signs and in the liturgical meanings of the sacraments, and the prayer in order to involve emotionally the believer, who only assists to the celebration. Pre-Council rites establish a separation between the presbytery and the nave through the insertion of gates and balusters, that also have the purpose to favor the holy communion in knee without, at the same time, impeding the sight of the Eucharistic tabernacle; the altar coram Deo, with the relics of the martyr, placed against the presbytery area wall and with an architectural structure above that frames the saint iconography; the prevalence of the Eucharistic Liturgy on the Word Liturgy, therefore of the altar and of the tabernacle on the ambon; the use of Latin during the religious function; a very short comment of the Scripture during the celebration and, as result, a predominance of sermons declaimed by the pulpit, something distinct by the Mass; the lack of a joint participation of the believers because of the minimized interaction in the liturgy, the little knowledge of the rite and the incomprehension of Latin often for the most part of the community; a limited use of the sacred music, performed only with the pipe organ and accompanied by Latin songs.

In comparison to the criterions established by the Council of Trent and followed until then, the Second Vatican Council introduces some radical changes inside the architectural space of churches (Concas, 2018b, p. 44-64). The Apostolic Constitution Sacrosanctum Concilium is exclusively devoted to the liturgical matter. The principal changes consist of: the removal of the separation between the presbytery and the nave; the insertion, recommended, of the altar versus populum to allow the celebration to be turned towards the ecclesia; the revision of the liturgical year; better functional and simpler rites; the unitary concept of the Mass, even though divided into Eucharistic and Word Liturgy; the reinstatement of the Believer's prayer; the use of the national language during the ceremony; the active participation of the believers, involved in the liturgy, even though with various roles; the use of other musical instruments different from the pipe organ; the introduction of popular religious songs and the promotion of a development of the contemporary sacred art. With these rules, that consider the ecclesia in particular, there is a change from the Council of Trent concept of 'assisting' to the Mass to the post-Council one of 'participating' actively and consciously.

In the following years, the Italian Episcopal Conference is devoted to this matter by publishing other instructions on specific themes, but it is in the first half of the Nineties that it issues the three principal rules (Concas, 2018b, p. 5860). These documents underline the care of the Italian Church in the cultural heritage and in the liturgical art and they show the wish to intervene on the existing architectural and artistic heritage and to create a new one. The pastoral Note on The adjustment of the churches according to the liturgical reform represents the explanatory text on this matter, because it indicates some methodological orientations and precise reference points.

This matter has a wide range, therefore, just some short notes on the liturgical 'improvement' of the presbytery area are here outlined, while the considerations on the spaces for Baptism and Penitence celebration and those on the other areas of the church are omitted (Concas, 2018b, p. 69-135). The observations comes from the direct reading of the present architectural space and the interventions in modern churches in Rome (Italy) already done. It has been chosen to examine the churches built between 1924 and 1965, because the liturgical reform has also involved those built, through changes during the works, in the years immediately before the Council or those built in the following years. There is a selection of some of the most meaningful churches from the historical-artistic point of view. Although every single architecture is unique for its size, architectural language and materials, the comparison is effective to infer the characteristics found and to compare the ties regarding the different operations.

The principal part in the 'improvement' of the presbytery consists of letting the three liturgical 'focuses' stand out altar versus populum, ambon and celebrant seat - and allowing the correct execution of the renovated rites.

From the installation type analysis, it emerges that the solutions adopted in its new definition are three: preservation of the architectural space and/not of the preexisting elements; lengthening of presbytery area; building of a new presbytery in front and separated by the existing one. In most of the parish churches, usually, balusters are removed to cancel the separation from the nave. According to the Council standard, it results opportune to distinguish the presbytery from the nave through an elevation, or through specific ornamental structures. So, some mobile or fixed 
platforms are set to highlight the presbytery in toto or only the new altar and, sometimes, also the other two 'focuses', otherwise the whole presbytery is redefined with several podiums of different largeness positioned on steps. In Sacro Cuore di Cristo Re, the new three liturgical 'focuses', made of green Carrara marble recalling to the altar coram Deo and preexisting baptismal font, are located on different floors made of dark Verzegnis red marble (Figure. 1). Different case in S. Pio X, where new liturgical structures are set on floors made of arabesque marble with a white background and light grey stains surrounded by grey-green veining. Here the ambon is made of bright Carrara marble that has been taken from one of the existing ambons with balcony situated, at the beginning, on each side of the presbytery, meanwhile it is kept the altar coram Deo backdrop, consisting of squared blocks in shaped stones, that has a hole in the middle to allow the integration of the new Eucharistic tabernacle and a new pipe organ upon itself (Figure. 2).

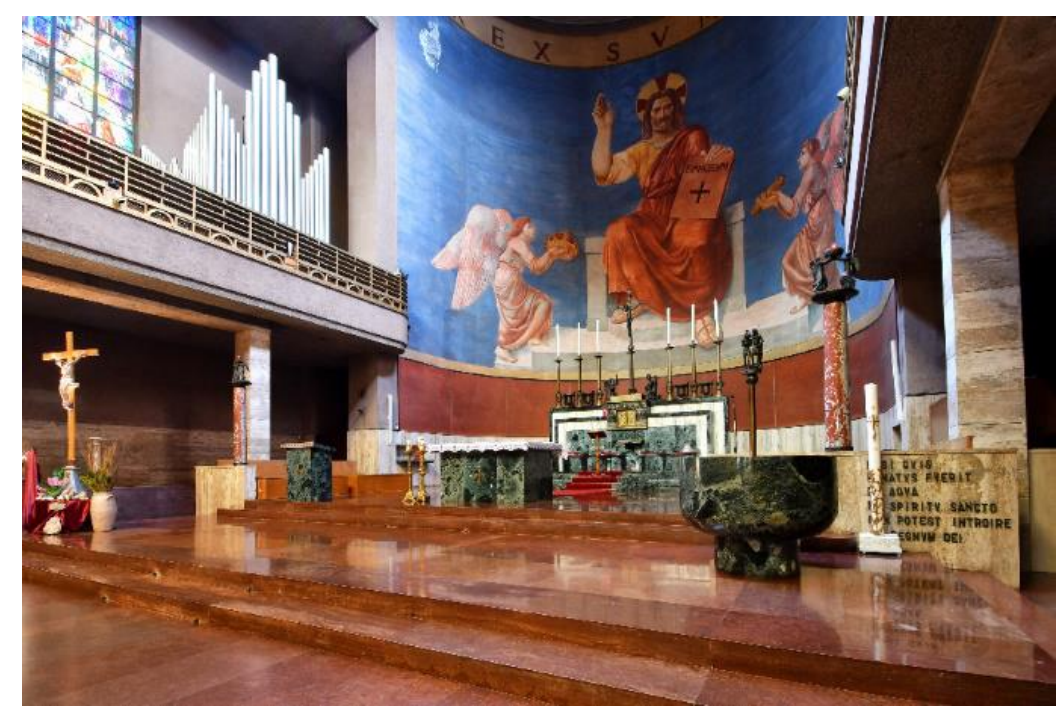

Figure 1. Sacro Cuore di Cristo Re (@ Roberto Nadalin).

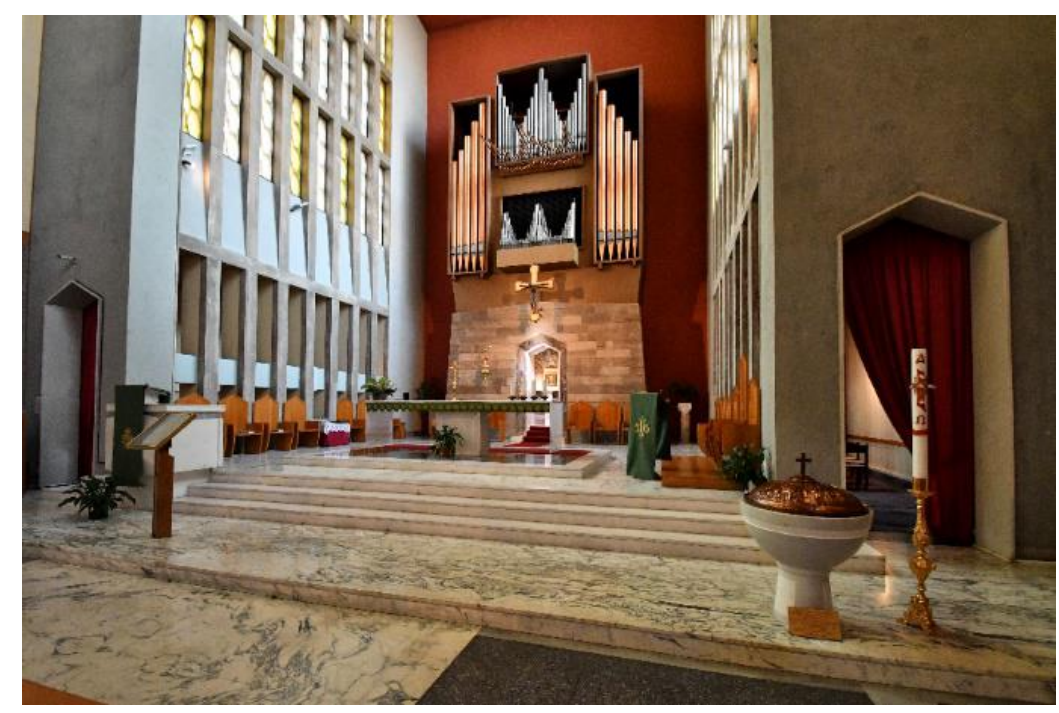

Figure 2. S. Pio X (@ Roberto Nadalin)

Most of the time there is a new presbytery configuration inside the original architectural space by eliminating all the preexisting elements and paying attention always on the principal liturgical 'focus', that is the new altar. In the modern churches, indeed, there are sporadic interventions that preserve the preexisting liturgical elements and ground this new definition on the good visibility from the ecclesia of the altar versus populum and of the liturgy that occurs there. In case of small presbyteries, it is impossible to create new liturgical areas, so the presbytery area is lengthened like in S. Benedetto da Norcia, where, furthermore, the altar coram Deo is kept by assuming the altar versus populum role (Figure. 3). Meanwhile, in churches of notable size, where the existing presbytery and the ecclesia are more distant from each other, a new presbytery is built like in Nostra Signora del Ss. Sacramento e dei SS. Martiri Canadesi, where 
the celebrant chair is positioned in the middle of the presbytery staircase and the altar versus populum is between the third and the fourth bays of the hall (Figure. 4).

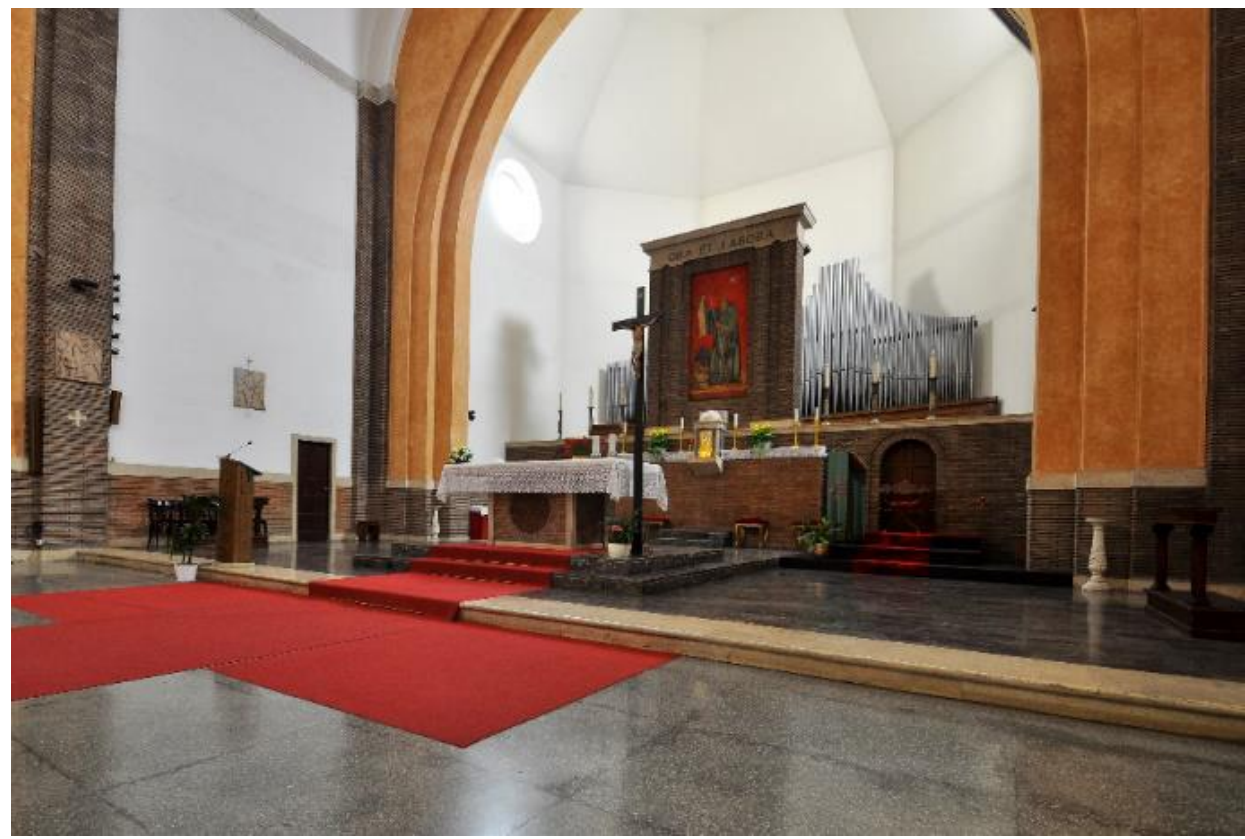

Figure 3. S. Benedetto da Norcia (๑ Roberto Nadalin).

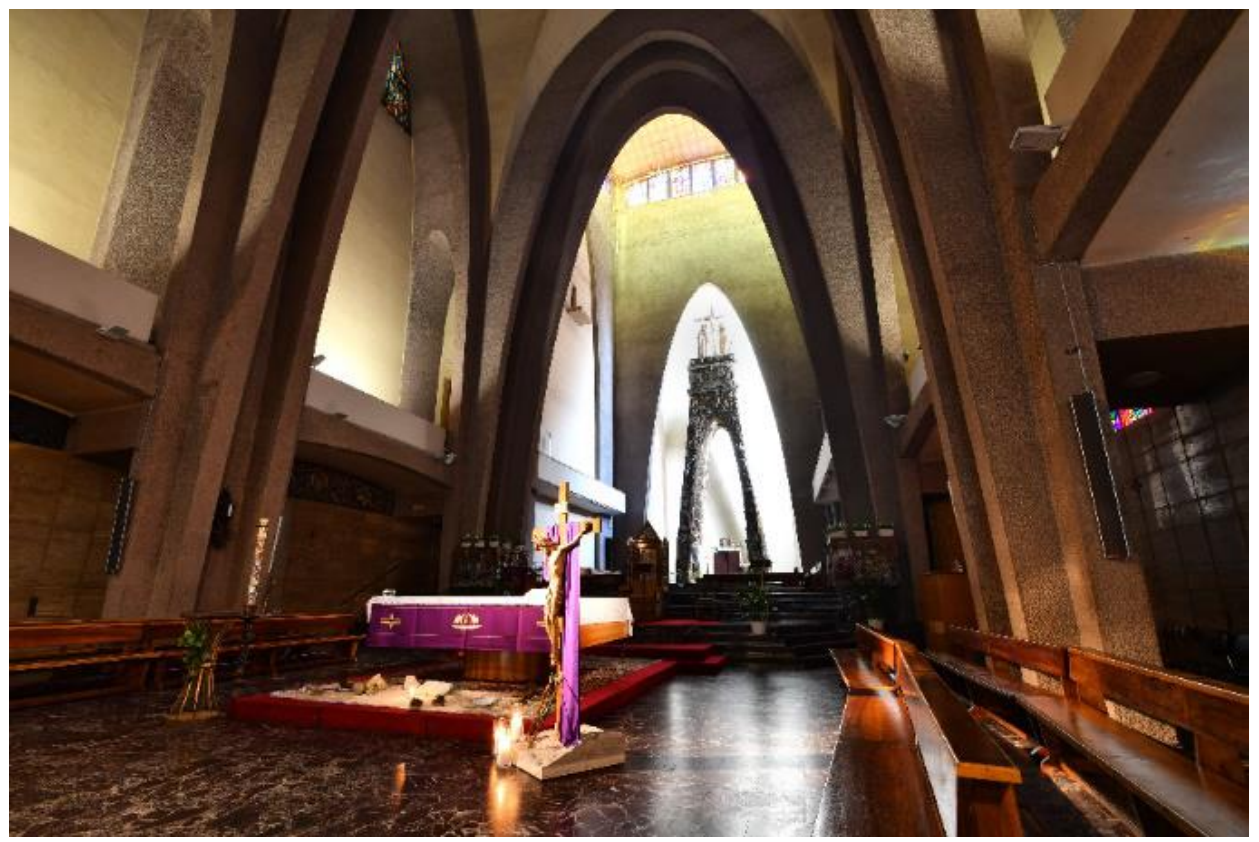

Figure 4. Nostra Signora del Ss. Sacramento (@ Roberto Nadalin).

Generally speaking, here it is shortly summarized the features of each liturgical element observed during the examination of the modern churches that have been selected in Rome.

The altar versus populum, table of Christ sacrifice and of Easter banquet, is the new principal focal point. For this reason, it is always well identified from everybody and it is placed in the middle of presbytery. It is usually projected as a fixed and permanent element that is positioned on a platform. Its shape is always rectangular or square. For the table it is preferred a slab of natural stone, another solid and fine material. For the jambs or the plinth different choices, both for shape and material, are taken: marble; granite; stone; travertine; bronze; copper; metal; concrete.

When the altar coram Deo is preserved, it is deprived of its liturgical meaning and becomes the table for the Eucharistic tabernacle, generally preexisting, and/or the polychrome backdrop of the new celebrants and ministers seats. 
According to the Council of Trent criterions, the tabernacle, the aedicule where the consecrated host is kept inside a pyx, represented the key element, because it highlights the Christ real presence, and was placed on the principal axis of the church and in an overlooking position above the altar. With the liturgical reform, it does not represent anymore the focal point that now becomes the altar versus populum, therefore its traditional position is now behind the new altar. The Eucharistic tabernacle must be one, fixed and closed with a key and only presbyters, deacons, special Eucharist ministers and sometimes the acolytes too have access to it. Most of the time, it is entirely included in the project of liturgical 'improvement' and becomes an architectural element in connection to the three 'focuses' for shape and material. Here it is preferred to put it inside the presbytery area, but there are examples where it is positioned in the Eucharistic chapel.

The ambon is the podium raised of some steps from the floor where the Scripture is proclaimed by the reader, the psalm is tuned up by the psalmist and the Gospel is explained by the celebrant. The new ambon is placed as connection between presbytery and nave to favor the listening of the believers. Its shape and materials are usually in relationship with the others two 'focuses'.

The celebrant seat is the liturgical place of who leads the celebration and guides the ecclesia during the prayer. It is always one, mobile and placed in its own space, sometimes raised from some steps. United to that of concelebrants seats, its position results prevailing behind the post-Council altar, often adjacent to the preexisting altar, other times, instead, it is before it or on its side. All the seats are, usually, an architectural element of shape and materials correlated to the other two liturgical areas.

\section{Conclusion}

Nowadays, the modern churches, liturgical architectures, have acquire a dual importance. First of all, they were and still are reference points and real answers for spiritual and material problems of local communities that live in districts born chaotically, at the beginning from the necessities and then from the property speculation. Secondly, even if they were built to actualize a spiritual project, they express a sensitive architectural and artistic sobriety according to their birth period and a humble and 'bare' faith like the then people desires. Therefore, they cannot be forgotten in the overview of the sacred building field in those years that faces, for the first time, the modern techniques without rejecting the loyalty to the tradition.

But, unfortunately, it is needed to notice that most of the time, the presbytery area has lost its natural role because it has been preferred a new liturgical 'improvement' without considering much the limits of the conservative works: in fact, the modern sacred area is conceived as a violable space, more than it is in the historical churches.

It is hoped that the technicians, who deal with the liturgical renewal projects, will be more sensitive to the preservation the memory of these architects: they searched for a new Catholic universality through a clear architectural expression of faith and were involved in the birth of the 'modern style'.

\section{References}

Benedetti Si. (2003). Significative realizzazioni di opera religiose a Roma negli anni tra le due guerre. In: Franchetti Pardo V., editor. L'architettura nelle città italiane del XX secolo. Dagli anni Venti agli anni Ottanta. Ascoli Piceno: Jaca Book. p. 182-189.

Carbonara G. \& Concas D. (2016). Alla ricerca di una nuova estetica per le nostre chiese, in Pontificium Consiglium Pro Laicis, editors. Incontrare Dio nel cuore della città. Roma: Lib. Ed. Vaticana, p. 155-169.

Concas D. (2015). Edificio-chiesa e città: l'inserimento del simbolo religioso nell'immagine urbana. In: Marmori A., Puccini L., Scandellari V., Van Riel S., editors. Architettura e città. Problemi di tutela e valorizzazione. Firenze: Altralinea, p. 69-78.

Concas D. (2018a). Le architetture liturgiche di Clemente Busiri Vici e Tullio Rossi, consulenti tecnici della Pontificia Opera per la Preservazione della Fede e la Provvista di nuove chiese in Roma. In: Niglio O., De Donà M., editors. Arte, Diritto e Storia. La valorizzazione del patrimonio culturale. Canterano (RM). Aracne EDA, p. 55-75.

Concas D. (2018b). Vademecum per l'adeguamento liturgico dell'edificio-chiesa di culto cattolico romano. Padova: il Prato.

Debuyst F. (2003). Chiese, arte, architettura, liturgia dal 1920 al 2000. Milano: Silvana.

Santi G. (2011). Nuove chiese in Italia (1861-2010). Sette lezioni. Milano: Vita e Pensiero. 